DOI https://doi.org/10.30929/2307-9770.2021.09.01.09

UDC 159.9.075: 519.23: 004.94: 371.2

\title{
Use of ICT for statistical analysis of psychological processes of future psychologists
}

\author{
Ostapenko Ya.* \\ University of State Fiscal Service of Ukraine, Irpin, Ukraine
}

Received: $02.03 .2021 \quad$ Accepted: 21.03.2021

\begin{abstract}
The use of computer technology in the educational process allows you to quickly and efficiently process large amounts of information obtained as a result of research and determine the impact of certain factors on the phenomenon or process under study. It is important for a psychologist to be able to properly analyze and process the data he receives as a result of psychological research. The use of statistical methods of data processing is an integral part of the analysis of psychological processes. The specificity of statistical processing of the results of psychological observations is that the database being analyzed is characterized by a large number of indicators of different types, their high variability under the influence of uncontrolled random phenomena, the complexity of correlations between variable samples. In this regard, one of the necessary conditions for the formation of research competence of a psychologist is to master the methods and criteria of statistical analysis. The article highlights the importance of mastering the statistical analysis of psychological phenomena and processes using computer technology for future psychologists. The essence of the main methods of statistical analysis is revealed: descriptive statistics, correlation analysis, methods of regression analysis, indicators of dynamics and detection of development trends, as well as forecasting the development of a psychological phenomenon or process in the future. The application of statistical methods using spreadsheets of Microsoft Excel is demonstrated, as the simplest and free, and therefore available to the average higher education-future psychologist and analysis of the results of processing indicators. Performing tasks of an applied nature with the use of computer technology helps to facilitate the perception of the material and a deeper mastery of the discipline "Statistical analysis and modeling of psychological processes" and the essence of the psychological processes themselves. Allows you to gain the skills of statistical analysis to find optimal solutions. The efficiency of using Microsoft Excel for statistical analysis of psychological phenomena is proved. The proposed methodological approach is implemented in the educational process. As a result of observation of classes the received results are generalized and systematized. Further research is proposed to model the phenomena and processes in psychology.
\end{abstract}

Key words: statistics; statistical analysis; computer technology in psychology; Microsoft Excel.

\section{Використання IKT для статистичного аналізу психологічних процесів майбутніх психологів \\ Остапенко Я. 0.}

Університет державної фріскальної служби України, Ірпінь, Україна

\begin{abstract}
Анотація. Використання комп'ютерних технологій в навчальному процесі дозволяє швидко та ефективно здійснювати обробку значних обсягів інфоормації, що отримуються в результаті дослідження та визначити вплив певних факторів на досліджуване явище чи процес. Психологу важливо вміти правильно аналізувати та обробляти дані, які він отримує в результаті проведеного психологічного дослідження. Застосування статистичних методів обробки даних $є$ невід'ємним етапом аналізу психологічних процесів. Специфіка статистичної обробки результатів психологічних спостережень полягає в тому, що база даних, яку аналізують, характеризується великою кількістю показників різних типів, їх високою варіативністю під впливом неконтрольованих випадкових явищ, складністю кореляційних зв'язків між змінними вибірками. У зв'язку з цим однією з необхідних умов формування дослідницької компетенції фахівця-психолога є оволодіння методами і критеріями статистичного аналізу. У статті висвітлено важливість засвоєння статистичного аналізу
\end{abstract}

\footnotetext{
Corresponding Author: Ostapenkko Yana Oleksandrivna. Tel. (096)9603190. E-mail: OstapenkoYO@gmail.com University of State Fiscal Service of Ukraine,

Universytetska St., 31, Irpin, Kyiv region, Ukraine, 08200.

Відповідальний автор: Остапенко Яна Олександрівна. Тел. (096)9603190. E-mail: OstapenkoYO@gmail.com Університет державної фіскальної служби України, вул. Університетська, 31, Ірпінь, Київська обл., Україна, 08200.
} 
психологічних явищ та процесів з використанням комп'ютерних технологій для майбутніх психологів. Розкрито сутність основних методів статистичного аналізу: описової статистики, кореляційного аналізу, методів регресійного аналізу, показників динаміки та виявлення тенденції розвитку, а також здійснення прогнозування розвитку психологічного явища чи процесу в майбутньому. Продемонстровано застосування статистичних методів із використанням електронних таблиць Microsoft Excel, як найпростішого та безкоштовного, а значить доступного для пересічного здобувача вищої освіти-майбутнього психолога, та проведення аналізу за отриманими результатами обробки показників. Виконання завдань прикладного характеру з використанням комп'ютерних технологій сприяє полегшенню сприйняття матеріалу та більш глибокого засвоєння дисципліни «Статистичний аналіз та моделювання психологічних процесів» та сутності самих психологічних процесів. Дозволяє отримати навички статистичного аналізу для пошуку оптимальних рішень. Доведено ефективність використання Microsoft Excel для статистичного аналізу психологічних явищ. Запропонований методичний підхід впроваджено у навчальний процес. У результаті спостереження за занятяяи узагальнено й систематизовано отримані результати. Подальші дослідження пропонується присвятити моделюванню явищ та процесів в психології.

Ключові слова: статистика; статистичний аналіз; комп'ютерні технології в психології; Microsoft Excel.

\title{
Использование ИКТ для статистического анализа психологических процессов будущих психологов
}

\author{
Остапенко Я. А. \\ Университет государственной фискальной службы Украины, Ирпень, Украина
}

\begin{abstract}
Аннотация. Использование компьютерных технологий в учебном процессе позволяет быстро и эффективно осуществлять обработку больших объемов информации, получаемых в результате исследования и определить влияние определенных факторов на изучаемое явление или процесс. Психологу важно уметь правильно анализировать и обрабатывать данные, которые он получает в результате проведенного психологического исследования. Применение статистических методов обработки данных является неотьемлемым этапом анализа психологических процессов. Специфика статистической обработки результатов психологических наблюдений заключается в том, что база данных, которую анализируют, характеризуется большим количеством показателей различных типов, их высокой вариативностью под влиянием неконтролируемых случайных явлений, сложностью корреляционных связей между переменными выборкам. В связи с этим одним из необходимых условий формирования исследовательской компетенции специалиста-психолога является овладение методами и критериями статистического анализа. В статье освещены важность усвоения статистического анализа психологических явлений и процессов с использованием компьютерных технологий для будущих психологов. Раскрыта сущность основных методов статистического анализа: описательной статистики, корреляционного анализа, методов регрессионного анализа, показателей динамики и выявление тенденции развития, а также осуществление прогнозирования развития психологического явления или процесса в будущем. Продемонстрировано применение статистических методов с использованием электронных таблиц Microsoft Excel, как простого и бесплатного, а значит доступного для рядового соискателя высшего образования-будущего психолога и проведения анализа по полученным результатам обработки показателей. Выполнение задач прикладного характера с использованием компьютерных технологий способствует облегчению восприятия материала и более глубокого усвоения дисциплины «Статистический анализ и моделирование психологических процессов» и сущности самих психологических процессов. Позволяет получить навыки статистического анализа для поиска оптимальных решений. Доказана эффрективность использования Microsoft Excel для статистического анализа психологических явлений. Предложенный методический подход внедрён в учебный процесс. В результате наблюдения за занятиями обобщены и систематизированы полученные результаты. Дальнейшие исследования предлагается посвятить моделированию явлений и процессов в психологии.

Ключевые слова: статистика; статистический анализ; компьютерные технологии в психологии; Microsoft Excel.
\end{abstract}

\section{Bcmyn}

Психолог, який володіє всебічними знаннями про психологічну реальність, має широкі можливості ефективно впливати на неї. Здобути такі знання за допомогою методології і методів лише гуманітарних наук неможливо. Щоб отримати об'єктивну її картину, потрібне вміння застосовувати й методи статистичного аналізу. У психології статистичні методи допомагають зробити процес дослідження явищ більш чітким, структурованим і раціональним. Вони необхідні для обробки великої кількості емпіричних даних. 
Засвоївши основні положення та методику статистичного аналізу з використанням IKT, фахівець 3 психології буде спроможним обробляти статистичні дані які отримані в результаті проведення різного роду психологічних експериментів, анкетування, встановлювати взаємозв'язки між різними факторами, аналізувати отримані дані, прогнозувати.

Сучасний ринок програмних продуктів пропонує різноманітні пакети програм для статистичної обробки різного роду показників. Питання полягає у виборі ефективних методів аналізу та програмних продуктів, які при цьому не потребували б значних витрат та були простими у використанні.

Для дослідження поведінки людини використовують багато різних математичних методів. У переважній більшості сучасних практичних і наукових літературних джерел соціально-психологічного напряму для аналізу досліджуваних проблем застосовують різні розділи математики, часом надто абстрактні. А розділ - математичну статистику використовують найчастіше. Застосуванню математичних методів та методів математичної статистики в психології свої праці присвятили науковці: Дж. Гласс, Дж. Стенли [1] А.В. Гришина[2], В.О. Климчук[3-4], Р. М. Літнарович[5], В. О. Олефір[6], В. М. Руденко, H. М Руденко[7], C.H Coombs., R.M. Dawes, A. Tversky[8] ,D. Howitt, D. Cramer,[9], R.L. Thorndike, E. Hagen [10].

Наукові праці з проведення статистичного аналізу психологічних явищ, зокрема з використанням прикладних програм, на вітчизняному та зарубіжному науковому просторі практично відсутні.

Використання програмних продуктів у статистичному аналізі розглядали : С.А. Айвазян, В.С. Степанова [11], Ж.В. Василенко[12], Р.Є. Майборода, О.В. Сугакова [13], Я.О. Остапенко[14-15], М.В. Роїк, O.I. Присяжнюк, В.О. Денисюк [16] Andry Field,[17], P. M. Bentler[18], D. Harrington[19], Ritz, Christian, Streibig, Jens [20], Spector Phil[21].

Але в даних працях здебільшого розглядаються статистичні програмні продукти, які потребують значних коштів на придбання та обслуговування, тому питання використання ефективних, але безкоштовних статистичних програм для психологічних досліджень $€$ актуальним.

Метою статmi є розгляд основних етапів статистичного аналізу психологічних досліджень 3 використанням електронних таблиць Microsoft Excel.

\section{II Матеріал і методи дослідження}

У процесі дослідження використовувались методи: аналіз наукової літератури, вивчення досвіду використання методик навчання та інноваційних підходів на заняттях статистичного аналізу психологічних процесів; спостереження за заняттями та їх аналіз; узагальнення й систематизація отриманих результатів. Методологічною основою дослідження $є$ комплексний підхід, що поєднує традиційні форми навчання та навчання 3 використанням комп'ютерних технологій, зокрема, електронних таблиць Microsoft Excel.

Процес статистичного аналізу психологічних процесів здійснюється в наступній послідовності:

1. Визначення показників для аналізу та постановка завдання. На даному етапі визначається мета статистичного аналізу психологічного явища(процесу) та відповідно до неї обираються показники для дослідження.

2. Визначення етапів статистичного аналізу та статистичних методів дослідження. Першим етапом аналізу даних, що утворюють статистичну сукупність, $€$ розрахунок показників описової статистики, що дають змогу оцінити у цілому, як веде себе досліджувана величина або величини за досить великих обсягів сукупностей об'єктів-носіїв цих величин, тобто проаналізувати характер розподілу цих величин. Наступним етапом дослідження, який дозволяє дослідити взаємозв'язок між показниками є кореляційно-регресійний аналіз. Кореляційно-регресійний аналіз, як випливає з назви, складається з двох незалежних етапів - кореляційного та регресійного. Мета першого - виявлення сили взаємозв'язку результативної та фракторної змінної (або змінних), другого - виду і параметрів такої залежності.

Силу взаємозв'язку зазвичай оцінюють за допомогою різних показників тісноти зв'язку, серед яких можна виділити непараметричні, або емпіричні: коефіцієнт кореляції рангів (коефіцієнт Спірмена), коефріцієнт Кендала, ранговий коефріцієнт згоди (коефіцієнт конкордації) і коефіцієнт взаємної спряженості Пірсона і параметричні, виведені строго математично: коефіцієнт кореляції знаків 
(коефріцієнт Фіхнера), коефіцієнт коваріації, лінійний коефріцієнт кореляції Пірсона, коефріцієнт детермінації та емпіричне кореляційне відношення.

Визначити напрям розвитку явища (процесу) можливо з використанням статистичних методів динаміки та тенденції розвитку. Для оцінки властивостей динаміки статистика використовує взаємопов'язані характеристики. Серед них абсолютний приріст, темп зростання, темп приросту і абсолютне значення 1\% приросту. Для визначення тенденції розвитку використовуються рівняння тренду.

3. Проведення статистичного аналізу з використанням програмних продуктів.

4. Узагальнення результатів аналізу та прийняття рішення.

\section{III Результати}

Розвиток інформаційних технологій та постійне вдосконалення пакетів прикладних програм дають змогу здійснювати пошук необхідної економічної інформації, створювати бази даних, проводити їх швидку та ефективну обробку, здійснювати глибокий аналіз та надавати результати у найбільш зручному вигляді.

Комп'ютерну реалізацію основних статистичних методів обробки даних передбачають електронні таблиці Microsoft Excel, які входять до складу пакету прикладних програм Microsoft Offce, QuattroPro та iH.

Для знаходження показників описової статистики на панелі інструментів електронної таблиці Microsoft Excel iснує вкладка (рис. 1):

\section{Данные $\rightarrow$ Анализ данных $\rightarrow$ Onисательная статистика / Data $\rightarrow$ Data Analysis $\rightarrow$ Descriptive Statistics.}

\begin{tabular}{|c|c|c|c|c|c|c|c|c|c|}
\hline \multirow{2}{*}{\multicolumn{2}{|c|}{\begin{tabular}{|l|} 
E4 \\
ла6. стат. *
\end{tabular}}} & \multicolumn{8}{|c|}{$\therefore \vee f_{x}$} \\
\hline & & \\
\hline 4 & A & B & c & $D$ & E & $\mathrm{F}$ & G & $\mathrm{H}$ & 1 \\
\hline 1 & Досліджуваннй & $\begin{array}{c}\text { Показннк } \\
\text { рівнятрнвожності } \\
\mathrm{x}\end{array}$ & $\begin{array}{c}\text { Кількість } \\
\text { правильних } \\
\text { відповідей у }\end{array}$ & & & & & & \\
\hline 2 & 1 & 2.8 & 8 & \multirow{2}{*}{\multicolumn{5}{|c|}{$\begin{array}{l}\text { Data Analysis } \\
\text { Analysis Tools }\end{array}$}} & \multirow[t]{2}{*}{$x$} \\
\hline 3 & 2 & 1,9 & 13 & & & & & & \\
\hline 4 & 3 & 2,9 & 5 & \multirow{3}{*}{\multicolumn{4}{|c|}{$\begin{array}{l}\text { Anova: Single Factor } \\
\text { Anova: Two-factor With Replication } \\
\text { Anova: Two-factor Without Replication } \\
\text { Correlation } \\
\text { Covariance }\end{array}$}} & $\wedge$ & \multirow[b]{2}{*}{ Cancel } \\
\hline 5 & 4 & 2 & 16 & & & & & & \\
\hline 6 & 5 & 3 & 11 & & & & & \multirow[b]{4}{*}{$\checkmark$} & довідка \\
\hline 7 & 6 & 3,1 & 6 & \multirow{3}{*}{\multicolumn{4}{|c|}{$\begin{array}{l}\text { Descriotive Statistics } \\
\text { Exponential Smoothing } \\
\text { F-Test Two-Sample for Variances } \\
\text { Fourier Analysis } \\
\text { Histogram }\end{array}$}} & & Довідка \\
\hline \multirow{2}{*}{8} & 7 & 2,8 & 9 & & & & & & \\
\hline & 8 & 1,6 & 18 & & & & & & \\
\hline 10 & 9 & 3,2 & 5 & & & & & & \\
\hline 11 & 10 & 3,3 & 2 & & & & & & \\
\hline 12 & & & & & & & & & \\
\hline 13 & & & & & & & & & \\
\hline
\end{tabular}

Рис. 1. Знаходження функції "Descriptive Statistic (Описова статистика)" в Microsoft Excel

Результати можна виводити на даний робочий лист (для цього необхідно зазначити вільну клітинку робочого листа в комірці "Output Range", або на новий робочий лист.

При статистичному аналізі важливо аналізувати отримані показники. Описова статистика дозволяє повністю проаналізувати наявний статистичний ряд даних, за такими показниками: середнє значення; стандартна похибка; медіана; мода; стандартна девіація; проста варіація; коефіцієнт ексцесу (куртозис); коефіцієнт асиметрії (skewness); мінімальне, максимальне значення; сума елементів тощо (рис. 2). 
Описова статистика рівня тривожності досліджуваних засвідчує, що: середній показник тривожності складає 2,66. При дослідженні найчастіше зустрічається показник рівня тривожності 2,8. Найбільший показник - 3,3, найменший - 1,6.

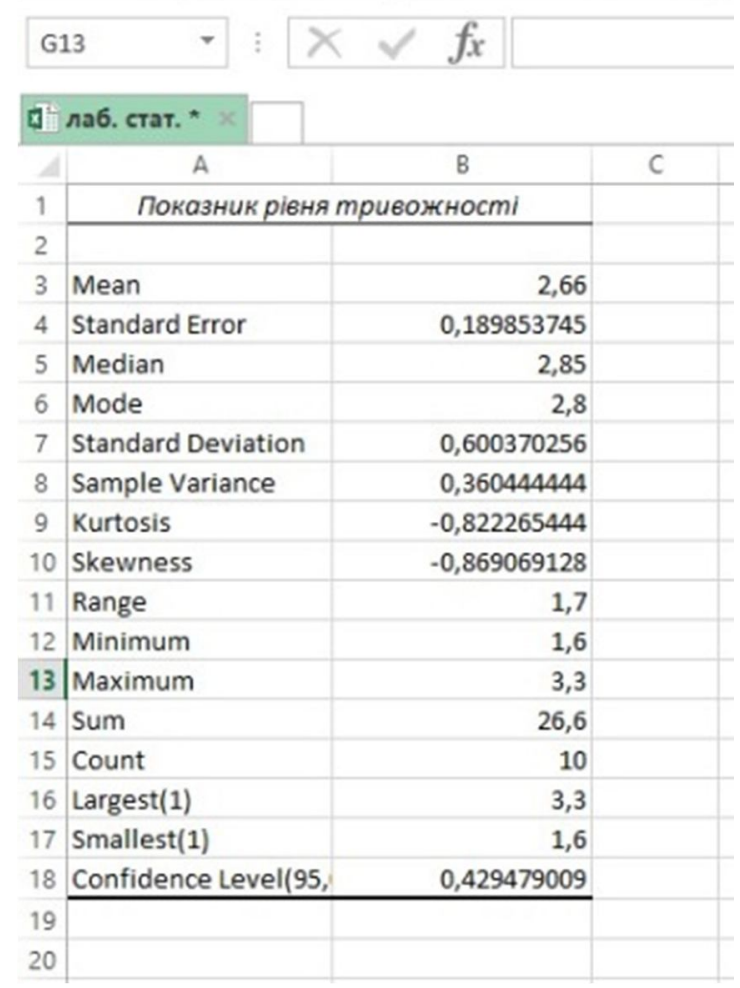

Рис. 2. Показники описової статистики рівня тривожності під час анкетування

у суспільному житті та психологічних дослідженнях часто доводиться вирішувати завдання, спрямовані на виявлення сили і характеру зв'язку між деякими величинами. Рішення подібного роду задач може допомогти спрогнозувати поведінку ознаки-результату за відповідного значення факторної ознаки або вибрати найкращий варіант рішення за факторною ознакою, який міг би дати бажане значення того чи іншого психологічного показника.

Для визначення парного коефріцієнта кореляції в Microsoft Excel застосовується функція "Корреляция"(Correlation), яка знаходиться у вкладці Данные $\rightarrow$ Анализ данных (Data $\rightarrow$ Data Analysis). Заповнюємо віконечко для обрахування коефіцієнта кореляції, як наведено на рис. 3.

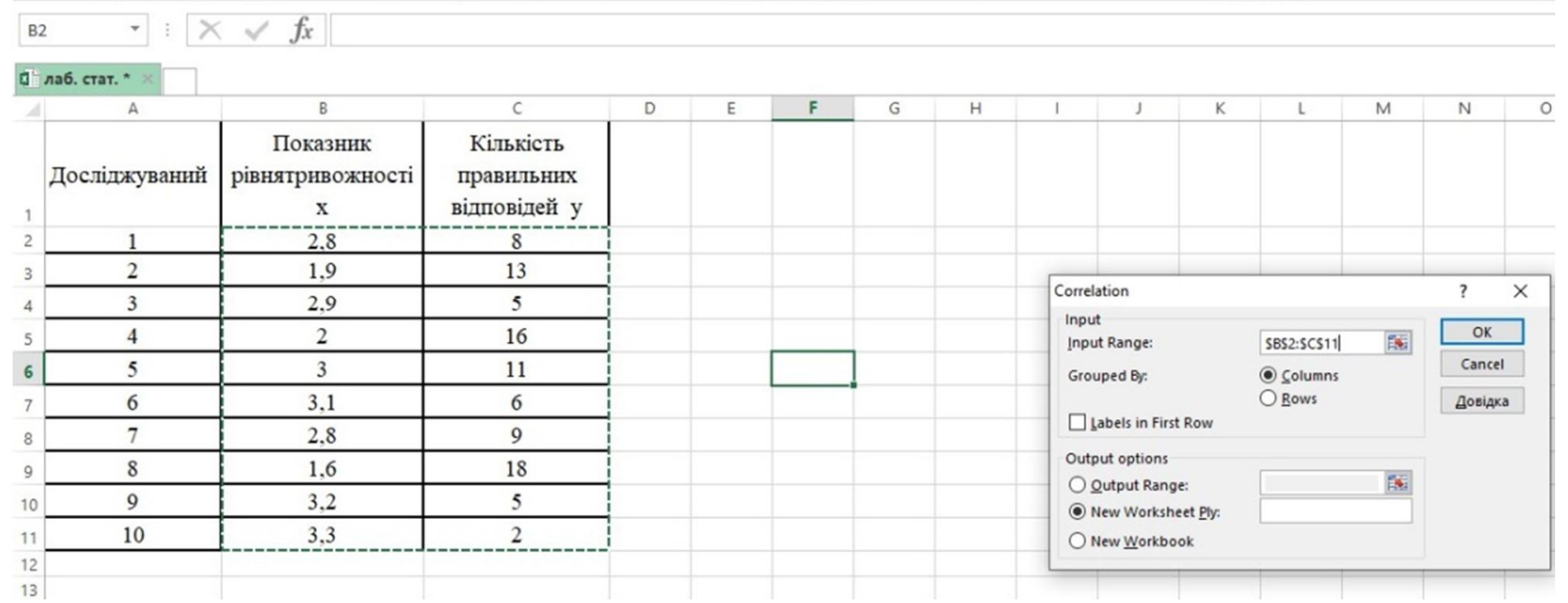

Рис. 3. Віконечко функції «Кореляція» пакету аналізу Microsoft Excel 
Окремим фрайлом Microsoft Excel виведе результати обчислення (рис. 4).

Отже, між показником тривожності і кількістю правильних відповідей існує тісний обернений зв'язок: на 91\% кількість правильних відповідей залежить від рівня тривожності. Тобто, чим більший показник тривожності, тим менше правильних відповідей надає опитуваний.

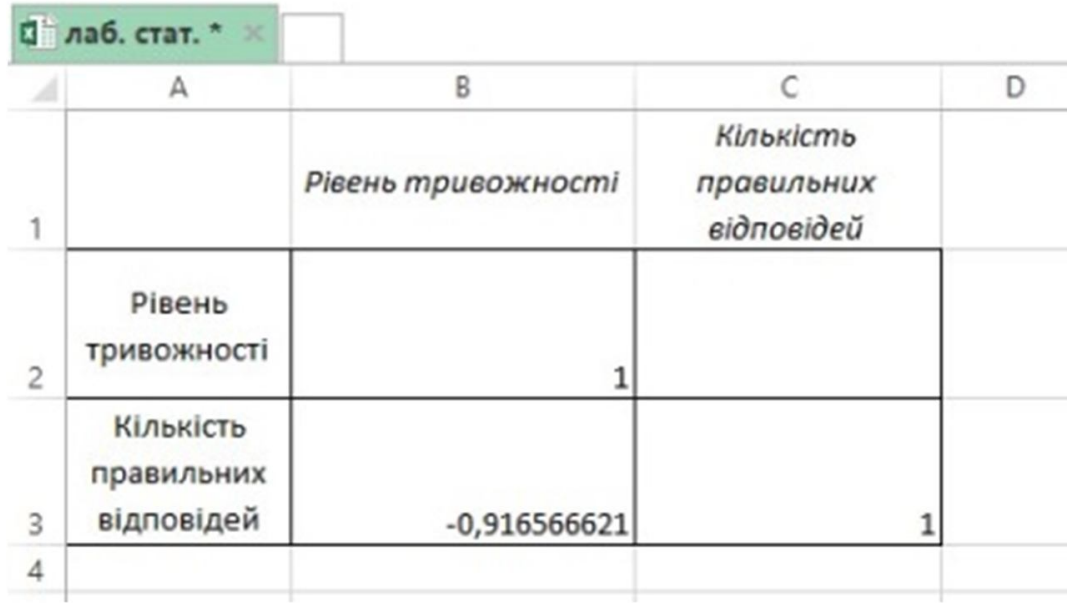

Рис. 4. Визначення щільності зв'язку між рівнем тривожності та кількістю правильних відповідей

Регресійний аналіз полягає у наближенні досліджуваного ряду розподілу результативного показника до ряду, який приблизно описує відповідність між результативною та фракторними ознаками при цьому завдяки наближенню за можливості виключається дія випадкових факторів.

Для визначення показників регресійної статистики в Microsoft Excel та побудови однофакторної моделі застосовується функція "Регресія"(Regression): Данные $\rightarrow$ Анализ данных $\rightarrow$ Регрессия $\rightarrow$ ОК. (Data $\rightarrow$ Data Analysis $\rightarrow$ Regression $\rightarrow O K)$. В клітинці вхідного інтервалу Y зазначаємо (охопивши мишкою) показники результативної ознаки (кількість правильних відповідей), вхідного інтервалу X показники фракторної ознаки (рівень тривожності). Вихідним інтервалом може бути або вільна клітинка робочого листа, або новий робочий лист (рис. 5).

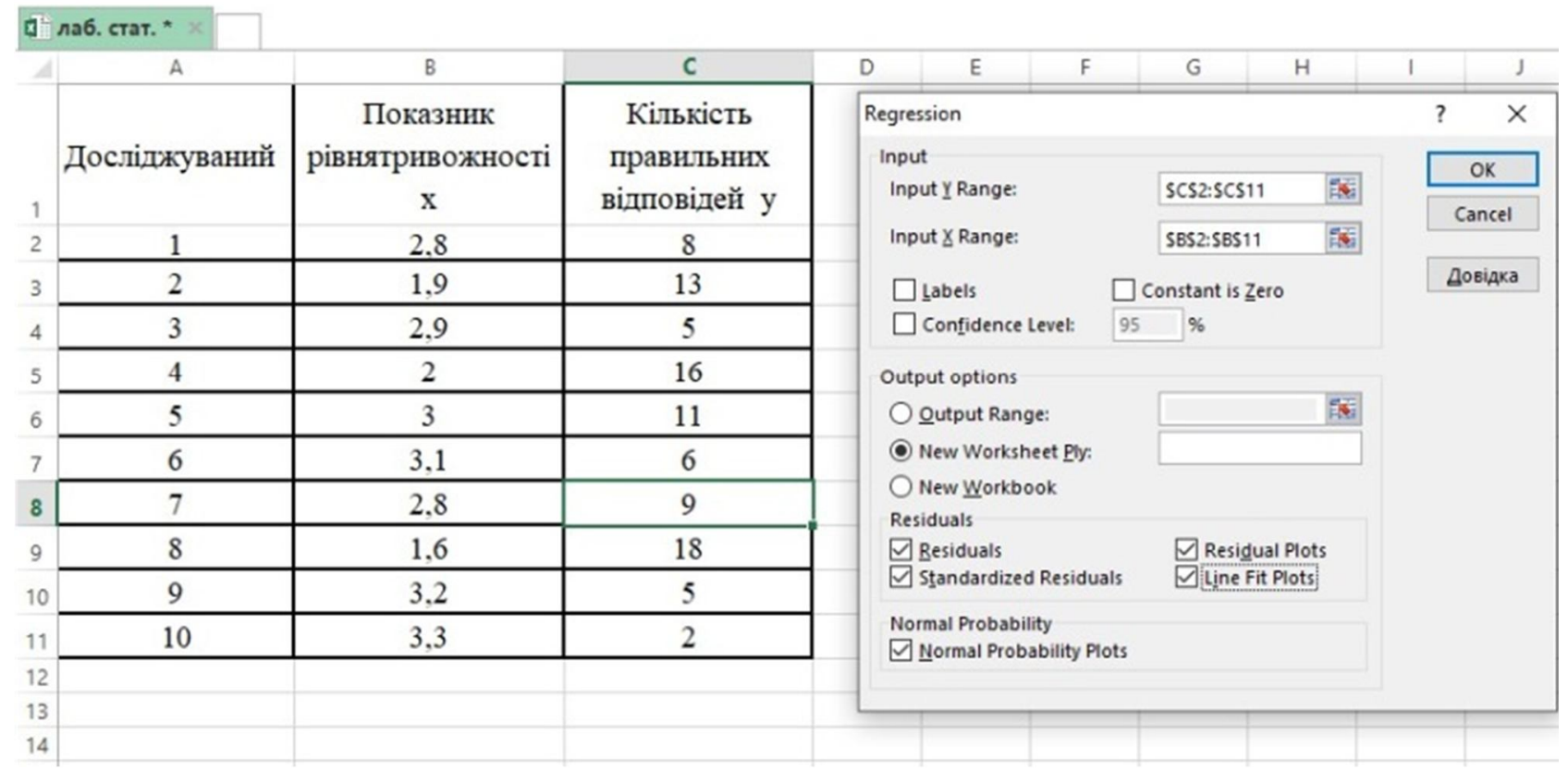

Рис. 5. Розрахунок показників регресійної статистики 
Результати отримані за даними дослідження представлені на рисунку 6.

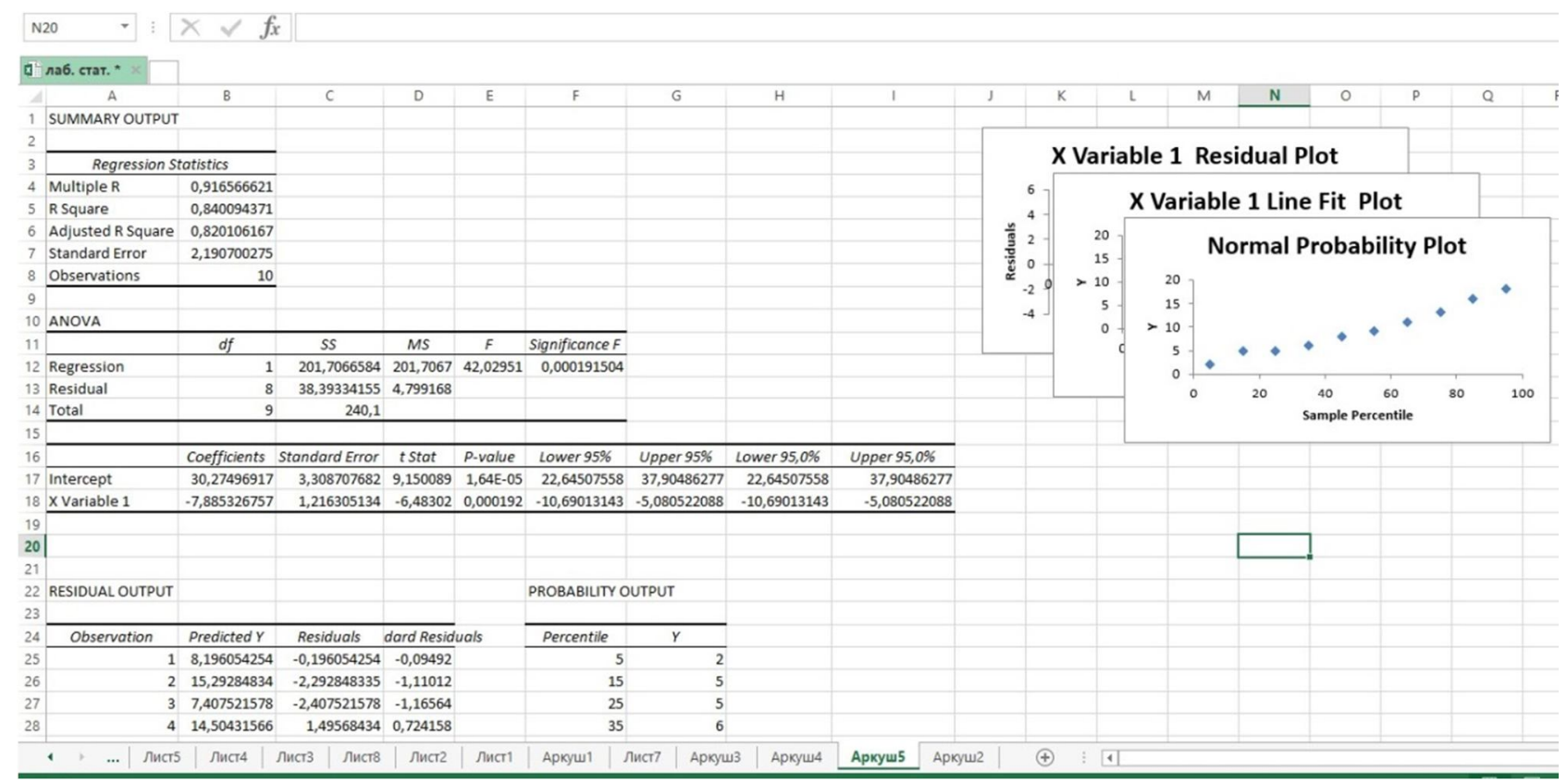

Рис. 6. Регресійний аналіз залежності кількості правильних відповідей від показника тривожності

Отримане лінійне рівняння

$$
Y=30,27-7,89 x
$$

Тобто, при зростанні показника тривожності на одиницю, кількість правильних відповідей зменшується на 7,89 .

Для дослідження психологічних явищ важливо відслідкувати їх динаміку та тенденцію розвитку. Для ефективних результатів дослідження необхідно обрати показники щонайменше за десять часових періодів, як наведено на рисунку 7.

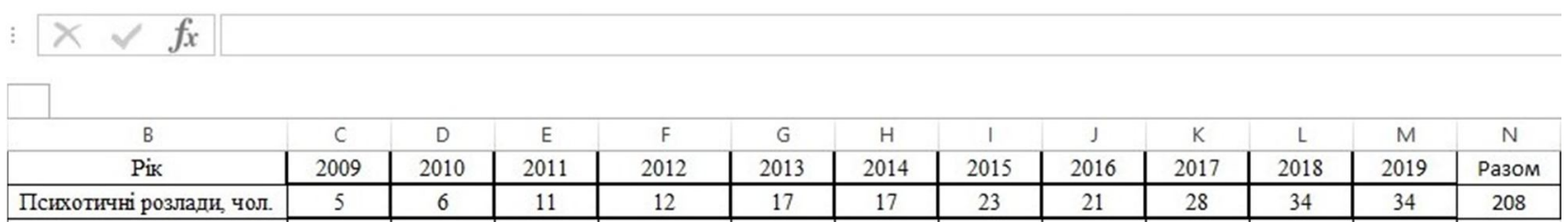

Рис. 7. Дані для розрахунку показників динаміки

Ми реалізували обчислення показників динаміки в Microsoft Excel в режимі фрормул, як показано на рисунку 8. Самі результати дослідження, наведені на рисунку 9.

За результатами дослідження можна зробити наступні висновки:

- максимальне збільшення розладів відбулось у 2017 році (на 7 осіб або на 33 \%) порівняно 3 2016 роком та на 23 особи ( порівняно з 2009 роком);

- зменшення розладів спостерігається у 216 році порівняно з 2015 роком на 2 особи або $8 \%$.

Для виявлення тенденції розвитку явища та його прогнозування необхідно використовуючи Майстер діаграм Microsoft Excel побудувати графік динаміки (рис. 10). 


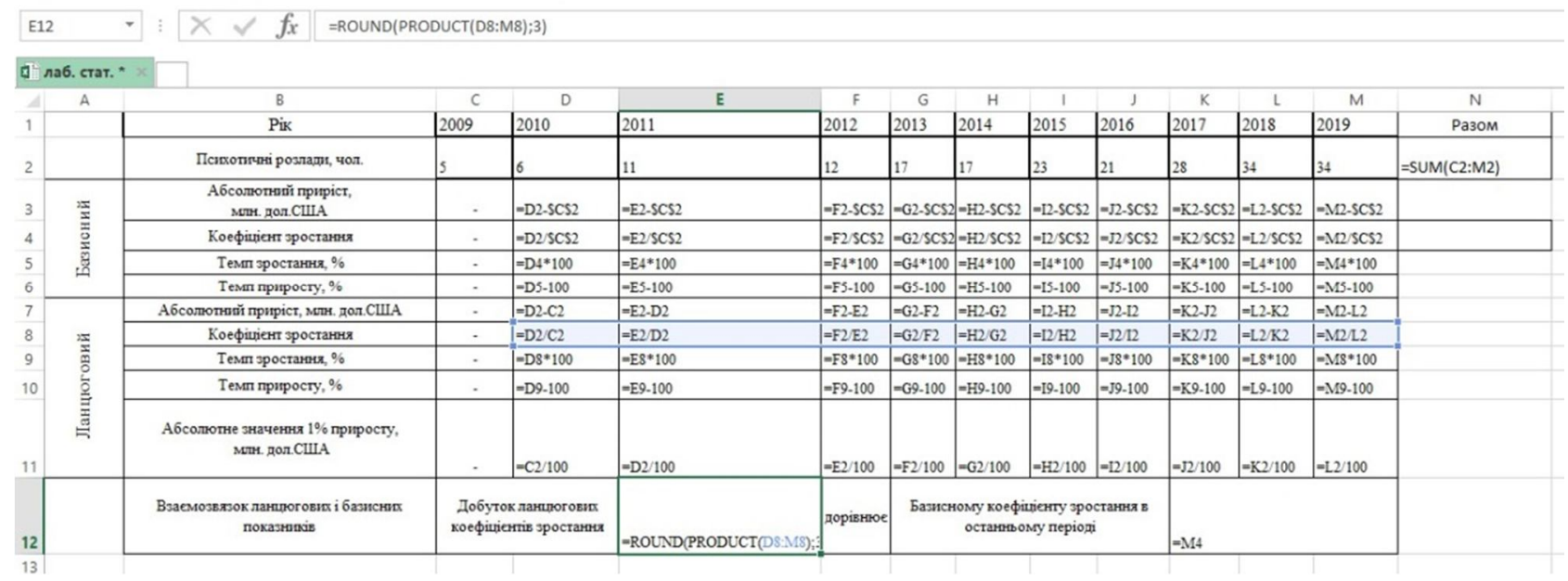

Рис. 8. Розрахунок показників динаміки Microsoft Excel

\begin{tabular}{|c|c|c|c|c|c|c|c|c|c|c|c|c|c|c|}
\hline \multicolumn{2}{|c|}{ 口. ла6. стат. * } & & & & & & & & & & & & & \\
\hline 4 & A & B & C & D & E & $\mathrm{F}$ & G & $\mathrm{H}$ & 1 & J & K & $\mathrm{L}$ & $M$ & N \\
\hline 1 & & Pik & 2009 & 2010 & 2011 & 2012 & 2013 & 2014 & 2015 & 2016 & 2017 & 2018 & 2019 & Разом \\
\hline 2 & & Психотичні розлади, чол. & 5 & 6 & 11 & 12 & 17 & 17 & 23 & 21 & 28 & 34 & 34 & 208 \\
\hline \multirow{4}{*}{$\begin{array}{l}3 \\
4 \\
5 \\
6\end{array}$} & \multirow{4}{*}{ 誊 } & $\begin{array}{l}\text { Абсолютний приріст, } \\
\text { млн. дол.США }\end{array}$ & - & 1 & 6 & 7 & 12 & 12 & 18 & 16 & 23 & 29 & 29 & \\
\hline & & Коефіцієнт зростання & - & 1,2 & 2,2 & 2,4 & 3,4 & 3,4 & 4,6 & 4,2 & 5,6 & 6,8 & 6,8 & \\
\hline & & Темп зростання, \% & - & 120 & 220 & 240 & 340 & 340 & 460 & 420 & 560 & 680 & 680 & \\
\hline & & Темп приросту, \% & - & 20 & 120 & 140 & 240 & 240 & 360 & 320 & 460 & 580 & 580 & \\
\hline 7 & \multirow{5}{*}{ 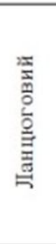 } & Абсолютний приріст, & - & 1 & 5 & 1 & 5 & 0 & 6 & -2 & 7 & 6 & 0 & \\
\hline \multirow{4}{*}{$\begin{array}{c}8 \\
9 \\
10\end{array}$} & & Коефіцієнт зростання & - & 1,2 & 1,8333 & 1,090909 & 1,4167 & 1 & 1,3529 & 0,913 & 1,3333 & 1,2143 & 1 & \\
\hline & & Темп зростання, \% & - & 120 & 183,33 & 109,0909 & 141,67 & 100 & 135,29 & 91,304 & 133,33 & 121,43 & 100 & \\
\hline & & Темп приросту, \% & - & 20 & 83,333 & 9,090909 & 41,667 & 0 & 35,294 & $-8,696$ & 33,333 & 21,429 & 0 & \\
\hline & & \begin{tabular}{|c|} 
Абсолютне значення $1 \%$ \\
приросту, \\
млн. дол.США \\
\end{tabular} & - & 0,05 & 0,06 & 0,11 & 0,12 & 0,17 & 0,17 & 0,23 & 0,21 & 0,28 & 0,34 & \\
\hline 12 & & $\begin{array}{c}\text { Взаємозвязок } \\
\text { ланцюгових і базисних } \\
\text { показників } \\
\end{array}$ & \multicolumn{2}{|c|}{$\begin{array}{c}\text { Добуток } \\
\text { ланцюгових } \\
\text { коефінієнтів }\end{array}$} & 6,8 & дорівнюе & \multicolumn{4}{|c|}{$\begin{array}{c}\text { Базисному коефіцієнту зростання в } \\
\text { останньому періоді }\end{array}$} & \multicolumn{3}{|c|}{6,8} & \\
\hline
\end{tabular}

Рис. 9. Показники динаміки психотичних розладів за 2009-2019 рр.

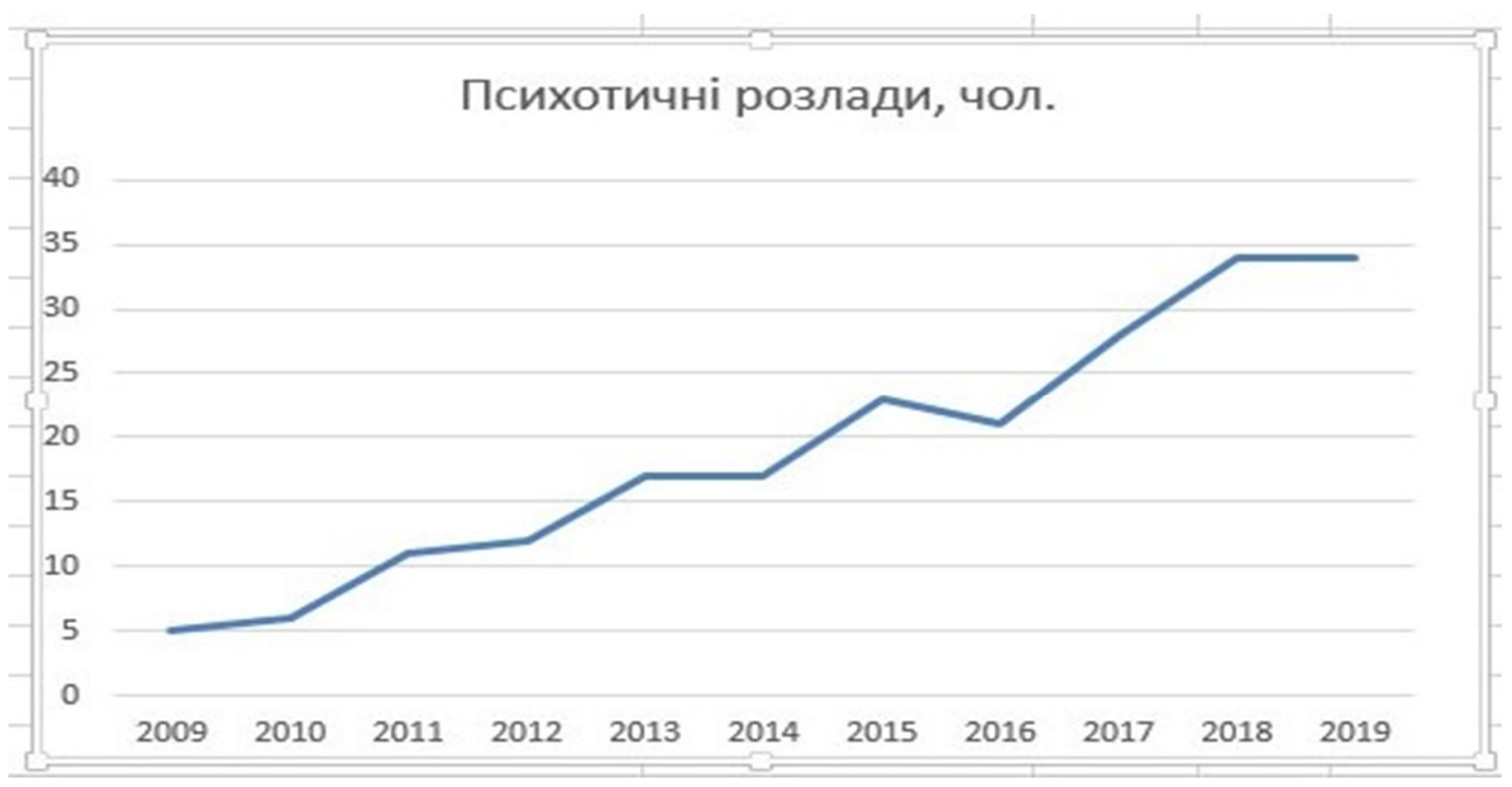

Рис. 10. Динаміка психотичних розладів за 2009-2019рр. 
Навівши курсор на графік, натиснути правою мишкою та обрати "Додати лінію тренду": ілюстрація наведена на рисунку 11. Із запропонованих Microsoft Excel трендів, шляхом підбору необхідно обрати лінійну, для цього обов'язково у віконечку "Формат лінії тренду", активуємо: "Показувати величину вірогідності апроксимації ( $\left.\mathrm{R}^{\wedge} 2\right)$ на діаграмі" та "Показувати рівняння на діаграмі". Далі по черзі підбираємо лінії тренду. Для зручності можна скласти таблицю 1.

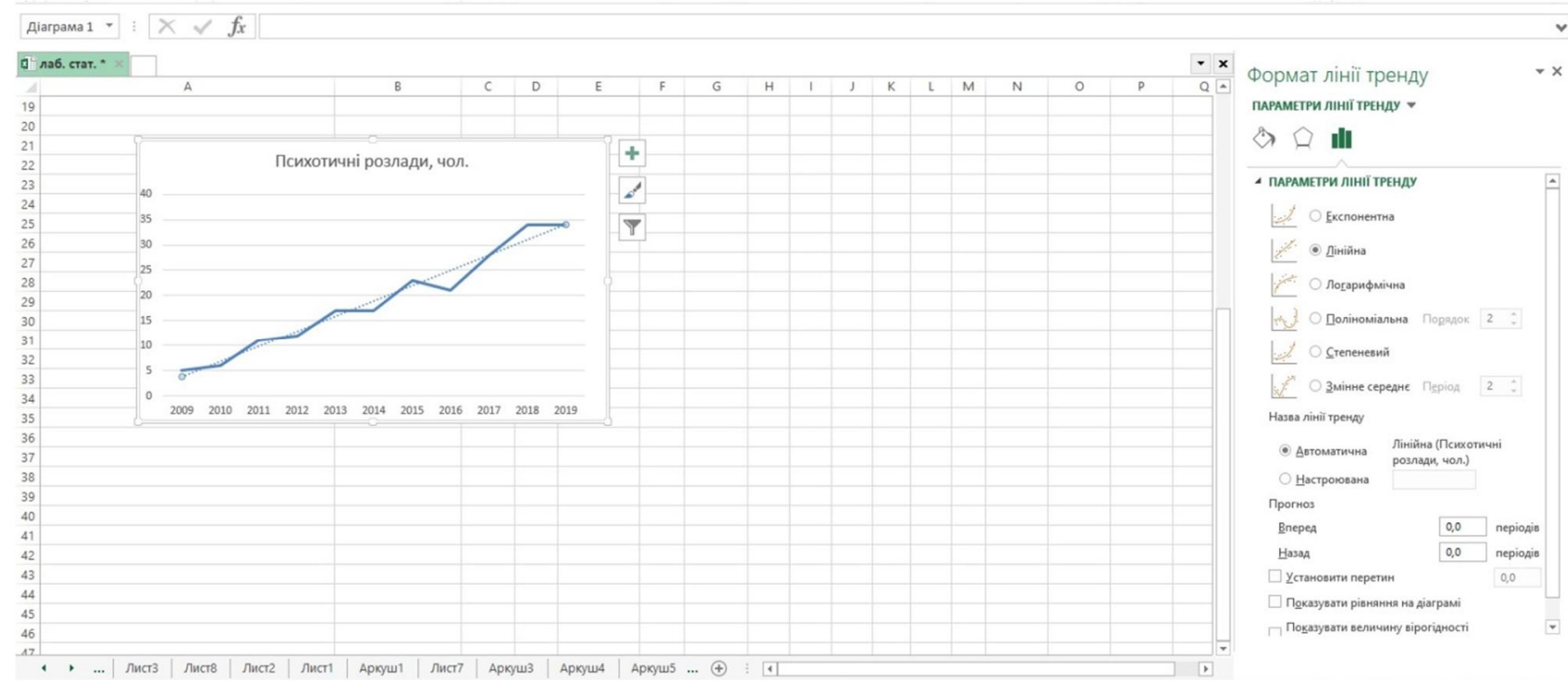

Рис. 11. Добавлення лінії тренду до графріку

Табл. 1. Визначення тенденції за рівнянням тренду

\begin{tabular}{|l|c|c|}
\hline \multicolumn{1}{|c|}{ Вид тренду } & Рівняння тренду & $\begin{array}{c}\text { Коесріцієнт } \\
\text { детермінації, } R^{2}\end{array}$ \\
\hline Лінійна & $\mathrm{y}=3,0182 \mathrm{x}+0,8$ & 0,9664 \\
\hline Логарифмічна & $\mathrm{y}=12,52 \ln (\mathrm{x})-1,0117$ & 0,8393 \\
\hline Степенева & $\mathrm{y}=4,1272 \mathrm{x}^{0,8526}$ & 0,9607 \\
\hline Експоненційна & $\mathrm{y}=51678,6 e^{0,18866 x}$ & 0,9316 \\
\hline
\end{tabular}

Для дослідження тенденції розладів найбільш якісним є лінійний тренд (рис. 12):

$$
R^{2}=0,9664 \text {. }
$$

Зробивши прогноз за лінією тренду, спостерігаємо тенденцію подальшого збільшення розладів.

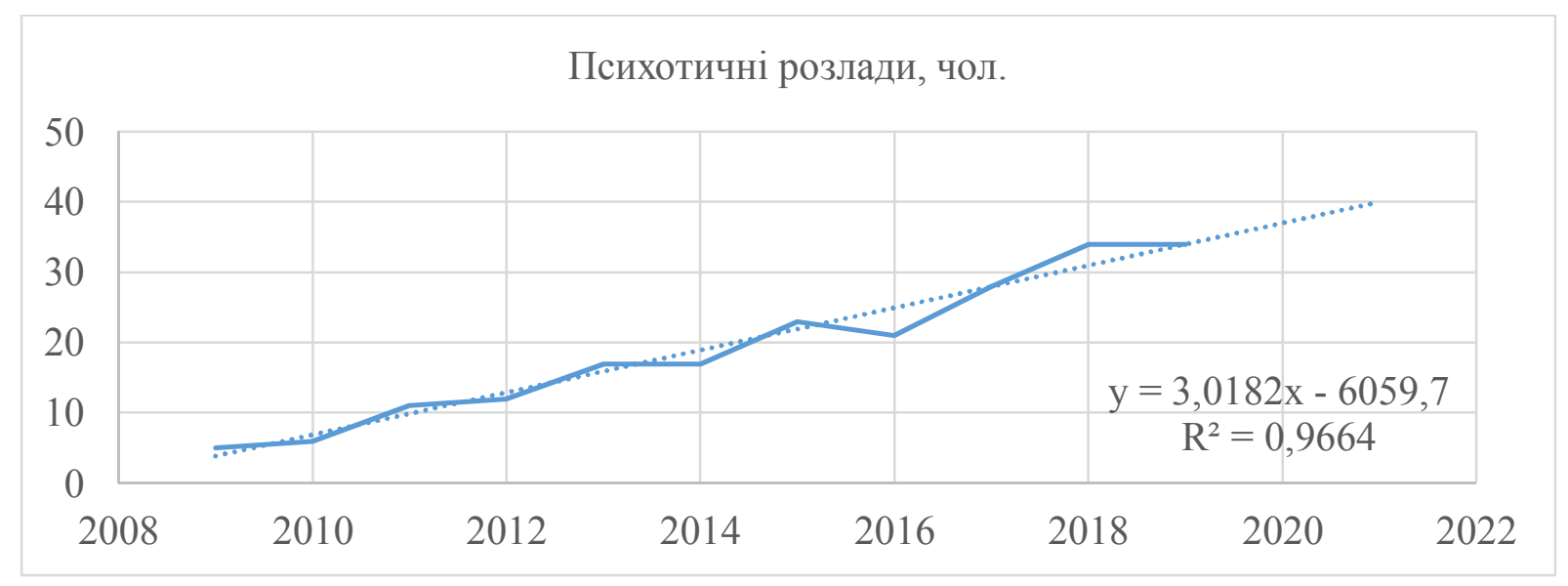

Рис. 12. Прогноз психотичних розладів за лінійним трендом 


\section{IV Обговорення}

У наведеному прикладі розглянуто методику статистичного аналізу психологічних явищ та процесів, як важливого інструментарію оброблення інформації 3 використанням комп'ютерних технологій, яка є обов'язковою частиною підготовки майбутнього повноцінного спеціаліста-психолога.

Для отримання надійних і достовірних результатів емпіричного аналізу психологічних процесів варто дотримуватися низки вимог:

1) дослідник повинен мати уявлення про логіку використаних статистичних методів;

2) застосовувати правильно підібрані статистичні методи для аналізу даних досліджень, адже множина статистичних методів буває достатньо різноманітною залежно від типу дослідження: емпіричного, прикладного або теоретичного.

3) варто попередньо провести пробну обробку на невеликій кількості масиву даних.

У процесі аналізу та узагальнення результатів умовно можна виділити кілька етапів:

1) упорядкування, класифікації, групування даних згідно з дослідницькими гіпотезами;

2) узагальнення даних, перевірку значущості й достовірності числових характеристик;

3) перевірку дослідницьких гіпотез за допомогою отриманих числових характеристик.

Запропонований методичний підхід до викладання дисципліни «Статистичний аналіз та моделювання психологічних процесів» для здобувачів вищої освіти за освітньою програмою «Психологія» спонукатиме студентів до більш глибокого розуміння як самої дисципліни, так i результатів психологічної діагностики, оволодінню навичками обробки та інтерпретації та прогнозуванню експериментальних даних. Використання комп'ютерних технологій при викладанні дисципліни та обробки інформації психологічних процесів дозволить зекономити час на обробку показників, більш чіткіше виявити тенденцію розвитку психологічного явища чи процесу, прийняти за результатами певні рішення, а також подати навчальний матеріал зрозуміліше, доступніше, цікавіше.

\section{V Висновки}

Отже, для проведення глибокого та ефективного статистичного аналізу психологічних явищ доцільно використовувати методи описової статистики, кореляційного, регресійного аналізу, показників динаміки, виявлення тенденції явища та на її основі прогнозування розвитку явища чи процесу на майбутнє. Швидко та ефективно обробити інформацію за даними напрямами аналізу можна за допомогою електронних таблиць Microsoft Excel, які має широкий спектр можливостей статистичної обробки даних, не потребує коштів на придбання та обслуговування, а також глибокої математичної підготовки користувачів.

Запропонована методика дослідження психологічних явищ та процесів дозволить розширити базу отриманих знань, полегшить сприйняття матеріалу, сприятиме більш глибокому розумінню психологічних експериментів.

Обов'язковою вимогою до повноцінного спеціаліста-психолога є володіння не тільки технологіями проведення досліджень, але й статистичним аналізом їх результатів та прогнозування розвитку психологічного явища (процесу) у майбутньому з використанням комп'ютерних технологій.

\section{Бібліографічні посилання}

1. Гласс Дж., Стенли Дж. Статистические методы в педагогике и психологии. М., 1976. 495 с.

2. Гришина А. В. Математичні методи в психології. Київ, Україна: Інститут кримінально-виконавчої служби, 2015.

3. Климчук В. О. Викладання курсу "Математичні методи у психології" в умовах кредитно-модульної системи / Соціальна психологія, №2 (28), 2008. С. 180-189.

4. Климчук В. О. Математичні методи у психології. Київ, Україна: Освіта України, 2009. 288 с.

5. Літнарович Р. М. Основи математичної статистики у психології. Рівне, Україна: МЕГУ, 2006. 49 с.

6. Олефрір В. О. Математичні методи в психології: методичні вказівки з організації та планування самостійної роботи студ для здобувачів освітньо-кваліфікаційного рівня бакалавр за спеціальністю 053 - психологія. Харків, Україна: Харківський національний університет імені В. Н. Каразіна, 2016. 59 с.

7. Руденко В. М., Руденко Н. М. Математичні методи в психології : підручник. Київ : Академвидав, 2017. 384 с.

8. Coombs C. H., Dawes R. M., Tversky A. Mathematical psychology: An elementary introduction, Englewood Cliffs: Prentice-Hall, $1970,419 p$.

9. Howitt D., Cramer D. Introduction to Statistics in Psychology. N.-Y.: FT, 2010. 
10. Thorndike R. L., Hagen E. Measurement and evaluation in psychology and education. N. Y.: L.: Wiley, 1961. 597 p.

11. Айвазян С. А., Степанов В. С. Программное обеспечение по статистическому анализу данных: методология сравнительного анализа и выборочный обзор рынка. URL: http://pubhealth.spb.ru/SAS/STatProg.htm. (дата звернення 18.02.21).

12. Василенко Ж. В. Программное обеспечение по статистическому анализу данных. Методология сравнительного анализа. URL: http://www.giac.unibel.by/sm_full.aspx?guid =8313. (дата звернення 20.02.21)

13. Майборода Р. Є., Сугакова О.В. Статистичний аналіз даних за допомогою пакету STATISTICA URL: http://matphys.rpd.univ.kiev.ua/downloads/courses/mmatstat/StatAn.doc. (дата звернення:15.02.21)

14. Остапенко Я. О. Використання PSPP під час статистичного аналізу, Східна Євроnа: економіка, бізнес та управління, №2 (13), 2018. URL: http://www. easterneurope-ebm.in.ua/index.php/13-2018-ukr (дата звернення:15.02.21)

15. Остапенко Я. О., Програмні продукти статистичних та економіко-математичних досліджень в економіці, International Scientific Conference Anti-Crisis Management: State, Region, Enterprise: Conference Proceedings, . Le Mans, France: Baltija Publishing, Part III, P.48-50, 17th, November, 2017.

16. Роїк М. В., Присяжнюк О. І., Денисюк В. О. Огляд програмних засобів статистичного аналізу даних, Ефеективна економіка, № 7, 2017. URL: http://www.m.nayka.com.ua/?op=1\&j=efektyvna-ekonomika\&s=ua\&z=5676 (дата звернення 15.02.21).

17. Andy Field. Discovering Statistics using SPSS. URL: https://www.discoveringstatistics.com/books/dsus/ (дата звернення 15.02.21).

18. Bentler P. M. EQS 6 Structural Equations Program Manual. Encino, CA: Multivariate Software, Inc., 2006. 418 p.

19. Harrington D. Confirmatory factof analysis. - New York : Oxford University Press, Inc., 2009. 122 p.

20. Ritz, Christian, Streibig, Jens Carl. Nonlinear Regression with R Springer-Verlag, New York, NY, 2008. ISBN 978-0-38709615-5. 144 pp.

21. Spector Phil Data Manipulation with R. 2008 Springer.157 p.

\section{References}

1. Glass, J., Stanley, J. (1976). Statistical methods in pedagogy and psychology.[Statisticheskie metody v pedagogike i psikhologii]. M., 495 p. [in Russia]

2. Hryshyna, A. V. (2015). Mathematical methods in psychology [Matematychni metody v psykholohiyi]. Kyiv, Ukraina: Instytut kryminalno-vykonavchoi sluzhby, [in Ukrainian].

3. Klymchuk, V. O. (2008). Teaching the course "Mathematical methods in psychology in terms of credit-module system"["Vykladannya kursu "Matematychni metody u psykholohiyi" v umovakh kredytno-modul'noyi systemy"], Sotsialna psykholohiia[,Sotsial'na psykholohiya], 2 (28), 180-189. [in Ukrainian].

4. Klymchuk, V. O. (2009). Mathematical methods in psychology [Matematychni metody u psykholohiyi]. Kyiv, Ukraina: Osvita Ukrainy. [in Ukrainian].

5. Litnarovych, R. M. (2006). Fundamentals of mathematical statistics in psychology[Osnovy matematychnoyi statystyky u psykholohiyi]. Rivne, Ukraina: MEHU. [in Ukrainian].

6. Olefir, V. O. (2016). Mathematical methods in psychology: guidelines for organizing and planning independent work of students. for applicants for educational qualification level bachelor's degree in specialty 053 - psychology [Matematychni metody v psykholohiyi: metodychni vkazivky z orhanizatsiyi ta planuvannya samostiynoyi roboty stud dlya zdobuvachiv osvitn'okvalifikatsiynoho rivnya bakalavr za spetsial'nistyu 053 - psykholohiya.]. Kharkiv, Ukraina: Kharkivskyi natsionalnyi universytet imeni V. N. Karazina.[in Ukrainian]

7. Rudenko, V. M., Rudenko, N. M. (2017). Mathematical methods in psychology: a textbook [Matematychni metody v psykholohiyi : pidruchnyk]. Kyiv: Akademvydav, $384 \mathrm{p}$.

8. Coombs, C. H., Dawes, R. M., Tversky, A. (1970). Mathematical psychology: An elementary introduction, Englewood Cliffs: Prentice-Hall, $419 \mathrm{p}$.

9. Howitt, D., Cramer, D. (2010). Introduction to Statistics in Psychology. N.-Y.: FT

10. Thorndike, R. L., Hagen, E. (1961). Measurement and evaluation in psychology and education. N. Y.: L.: Wiley, 597 p.

11. Aivazian, S. A., Stepanov, V. S. (2021). Statistical data analysis software: benchmarking methodology and sample market overview[Programmnoe obespechenie po statisticheskomu analizu dannykh: metodologiya sravnitelnogo analiza i vyborochnyy obzor rynka]. URL: http://pubhealth.spb.ru/SAS/STatProg.htm. (accessed: 18.02.21). [in Russia ]

12. Vasylenko, Zh. V. Programmnoe obespechenie po statisticheskomu analizu dannykh. Metodologiya sravnitelnogo analiza]. Statistical data analysis software: benchmarking methodology and sample market overview. URL: //www.giac.unibel.by/sm_full.aspx?guid =8313 (accessed 20.02.21) [in Russia]

13. Maiboroda, R. le., Sugakova, O. V. (2021). Statistical analysis of data using the STATISTICA package [Ctatystychnyy analiz danykh za dopomohoyu paketu STATISTICA]. URL: http://matphys.rpd.univ.kiev.ua/downloads/courses/mmatstat/StatAn.doc. (accessed 15.02.21) [in Ukrainian]

14. Ostapenko, Ya. O. (2018). Use of PSPP during statistical analysis[Vykorystannya PSPP pid chas statystychnoho analizu]. Skhidna Yevropa: ekonomika, biznes ta upravlinnia, №2 (13). URL: http://www.easterneurope-ebm.in.ua/index.php/13-2018ukr (accessed 15.02.21). [in Ukrainian]

15. Ostapenko, Ya. O. (2017). Software products of statistical and economic-mathematical research in economic [Prohramni produkty statystychnykh ta ekonomiko-matematychnykh doslidzhen' v ekonomitsi]. International Scientific Conference Anti- 
Crisis Management: State, Region, Enterprise: Conference Proceedings, . Le Mans, France: Baltija Publishing, Part III, P.4850, 17th, November, [in Ukrainian]

16. Roik, M. V., Prysyazhnyuk, O. I., Denisyuk, V. O. (2017). Review of software for statistical data analysis [Ohlyad prohramnykh zasobiv statystychnoho analizu danykh], Effective Economics [Efektyvna ekonomika], № $7 . \quad$ URL: http://www.m.nayka.com.ua/?op=1\&j=efektyvna-ekonomika\&s=ua\&z=5676 (accessed 15.02.21). [in Ukrainian]

18. Bentler, P. M. (2006). EQS 6 Structural Equations Program Manual. Encino, CA: Multivariate Software, Inc., 418 p.

19. Harrington, D.(2009). Confirmatory factof analysis. - New York : Oxford University Press, Inc., 122 p.

20. Ritz, Christian, Streibig, Jens Carl.(2008) Nonlinear Regression with R Springer-Verlag, New York, NY ISBN 978-0-387-096155. $144 \mathrm{pp}$.

21. Spector, Phil (2008). Data Manipulation with R. Springer.157 p.

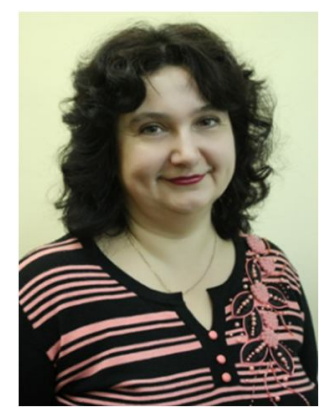

\section{Остапенко Яна Олександрівна.}

Кандидат економічних наук, доцент, доцент кафедри управлінського обліку, бізнес-аналітики та статистики, Університет державної фіскальної служби України, вул. Університетська, 31, Ірпінь, Київська обл., Україна, 08200. Тел. (096)9603190. E-mail: OstapenkoYO@gmail.com

\section{Ostapenkko Yana Oleksandrivna.}

Ph. D. in Economics, Associate Professor of Managerial Accounting, Business Analytics and Statistics Department University of State Fiscal Service of Ukraine, Universytetska St., 31, Irpin, Kyiv region, Ukraine, 08200. Tel. (096)9603190. E-mail: OstapenkoYO@gmail.com

ORCID: https://orcid.org/0000-0002-9386-2237

Scopus ID: 57189044168

\section{Citation (APA):}

Ostapenko, Ya. (2021). Use of ICT for statistical analysis of psychological processes of future psychologists. Engineering and Educational Technologies, 9 (1), 102-113. doi: https://doi.org/10.30929/2307-9770.2021.09.01.09

\section{Цитування (ДСТУ 8302:2015):}

Остапенко Я. О. Використання ІКТ для статистичного аналізу психологічних процесів майбутніх психологів / Інженерні та освітні технологіï. 2021. Т. 9. № 1. С. 102-113. doi: https://doi.org/10.30929/2307-9770.2021.09.01.09

Обсяг статті: сторінок - 12; умовних друк. аркушів - 1,738. 